\title{
New ribosome-inactivating proteins and other proteins with protein synthesis-inhibiting activities
}

Jack Ho Wong 1 2, Hui Bao 3, Tzi Bun Ng 4, Helen Hei Ling Chan 5, Charlene Cheuk Wing $\mathrm{Ng}$ 6, Gene Chi Wai Man 7, Hexiang Wang 8, Suzhen Guan 9, Shuang Zhao 10, Evandro Fei Fang 11 12, Krzysztof Rolka 13, Qin Liu 14, Chunman Li 15, Ou Sha 15, Lixin Xia 16

Affiliations

1Department of Anatomy, Histology and Embryology, School of Basic Medical Sciences, Shenzhen University, Shenzhen, China. jack1993@yahoo.com.

2State Key Laboratory of Respiratory Disease for Allergy, School of Medicine, Shenzhen University, Shenzhen, Guangdong, China. jack1993@yahoo.com.

3State Key Laboratory of Respiratory Disease for Allergy, School of Medicine, Shenzhen University, Shenzhen, Guangdong, China.

4School of Biomedical Sciences, Faculty of Medicine, The Chinese University of Hong Kong, Hong Kong, China. tzibunng@cuhk.edu.hk.

5Vita Green Pharmaceuticals (Hong Kong) Limited, Hong Kong, China. helen.chan@vitagreen.com.

6School of Medicine, King's College London, London, UK.

7Department of Orthopedics and Traumatology, The Chinese University of Hong Kong, Hong Kong, China.

8Department of Microbiology, China Agricultural University, Beijing, China.

9Department of Social Medicine, College of Public Health, Xinjiang Medical University, Urumqi, China.

10Institute of Plant and Environment Protection, Beijing Academy of Agriculture and Forestry Sciences, and Beijing Key Laboratory of Fruits and Vegetable Storage and Processing, Key Laboratory of Vegetable Postharvest Processing, Ministry of Agriculture, Beijing, China.

11Department of Clinical Molecular Biology, University of Oslo and Akershus University Hospital, Lørenskog, Norway.

12The Norwegian Centre on Healthy Ageing (NO-Age), Oslo, Norway.

13Department of Molecular Biochemistry, Faculty of Chemistry, University of Gdańsk, Wita Stwosza 63, Gdańsk, Poland.

14Institute of Plant Nutrition, Agricultural Resources and Environmental Science, Henan Academy of Agricultural Sciences, Zhengzhou, China.

15Department of Anatomy, Histology and Embryology, School of Basic Medical Sciences, Shenzhen University, Shenzhen, China.

16State Key Laboratory of Respiratory Disease for Allergy, School of Medicine, Shenzhen University, Shenzhen, Guangdong, China. xialixin@szu.edu.cn. 


\begin{abstract}
Ribosome-inactivating proteins (RIPs) consist of three varieties. Type 1 RIPs are singlechained and approximately $30-\mathrm{kDa}$ in molecular weight. Type $2 \mathrm{RIPs}$ are double-chained and composed of a type 1 RIP chain and a lectin chain. Type III RIPs, such as maize b-32 barley and JIP60 which are produced as single-domain proenzymes, possess an $\mathrm{N}$-terminal domain corresponding to the A domain of RIPs and fused to a C-terminal domain. In addition to the aforementioned three types of RIPs originating from flowering plants, there are recently discovered proteins and peptides with ribosome-inactivating and protein synthesis inhibitory activities but which are endowed with characteristics such as molecular weights distinctive from those of the regular RIPs. These new/unusual RIPs discussed in the present review encompass metazoan RIPs from Anopheles and Culex mosquitos, antimicrobial peptides derived from RIP of the pokeweed Phytolacca dioica, maize RIP (a type III RIP derived from a precursor form), RIPs from the garden pea and the kelp. In addition, RIPs with a molecular weight smaller than those of regular type 1 RIPs are produced by plants in the Cucurbitaceae family including the bitter gourd, bottle gourd, sponge gourd, ridge gourd, wax gourd, hairy gourd, pumpkin, and Chinese cucumber. A small type II RIP from camphor tree (Cinnamomum camphora) seeds and a snake gourd type II RIP with its catalytic chain cleaved into two have been reported. RIPs produced from mushrooms including the golden needle mushroom, king tuber mushroom, straw mushroom, and puffball mushroom are also discussed in addition to a type II RIP from the mushroom Polyporus umbellatus. Bacterial (Spiroplasma) RIPs associated with the fruitfly, Shiga toxin, and Streptomyces coelicolor RIP are also dealt with. The aforementioned proteins display a diversity of molecular weights, amino acid sequences, and mechanisms of action. Some of them are endowed with exploitable antipathogenic activities.
\end{abstract}




\section{Introduction}

Ribosome-inactivating proteins are characterized by the ability to inhibit protein synthesis. They have drawn a great deal of attention because of the plethora of exploitable activities including anticancer, antifungal, antibacterial, antiviral, and insecticidal activities (Stirpe and Lappi 2014; Akkouh et al. 2015; Zhu et al. 2018). Ribosome-inactivating proteins (RIPs) comprise type I RIPs which are single-chained proteins with a molecular weight in the vicinity of $30 \mathrm{kDa}$ and type II RIPs composed of a type 1 RIP chain and a lectin chain (Fabbrini et al. 2017; Zhu et al. 2018).

Type I and type II RIPs may co-exist in the same plant tissue (de Benito et al. 1995). Type II RIPs consist of both toxic and nontoxic proteins. Though nontoxic RIPs have lower anticancer activity, their conjugates with other molecules can be used to target against cancer (Girbés et al. 1993; Girbes et al. 2003; De Benito et al. 1995; Muñoz et al. 2001; Citores et al. 2002). The list of unique RIPs covered in this review include those from mosquitos and bacteria, the kelp Laminaria japonica, the gymnosperm cypress tree, maize (a type 3 RIP derived from a precursor), peptides prepared from Phytolacca RIP, garden pea RIP, small RIPs from flowering plants in the Cucurbitaceae family, a small type II RIP from camphor tree (Cinnamomum camphora) seeds, a type II RIP from the mushroom Polyporus umbellatus, mushroom RIPs, a type 2 RIP from snake gourd seeds with a cleaved catalytic chain, and bacterial RIPs including Spiroplasma RIP, Shiga toxin and Streptomyces coelicolor RIP. The aim of this article is to review new types of proteins with ribosome-inactivating and protein synthesis inhibitory activities.

\section{Mosquito RIPs}

\section{Culex quinquefasciatus RIP and Aedes aegypti RIP}

Genes coding for RIPs in the mosquito species $C$. quinquefasciatus and A. aegypti have been described. Results of assessment of taxonomic distribution, phylogenetic inferences, and microsynteny analyses suggest the origin of mosquito RIP genes from a single horizontal gene transfer (HGT) event, presumably from a cyanobacterial donor. Evolutionary analyses disclose that, subsequent to the HGT event, the mosquito RIP genes evolved under purifying selection, implying functional roles in mosquitos (Lapadula et al. 2017).

\section{Algal RIP}

Lamjapin

Lamjapin, a 36-kDa type I RIP from kelp (L. japonica A), is the first RIP reported from a marine alga. It exhibited cell-free protein synthesis in the inhibitory activity in rabbit reticulocyte lysate with an IC50 of $0.69 \mathrm{nM}$. It was capable of cleaving purine at multiple sites of RNA in the rat ribosome to yield the diagnostic $\mathrm{R}$-fragment and three bigger fragments following addition of aniline. Lamjapin split the adenyl residue at the site A20 of the 35-mer synthetic oligoribonucleotide substrate used to simulate the sarcin/ricin domain in 28S RNA from rat ribosomes. It was incapable of catalyzing the hydrolysis of the N-C glycosidic bond in cytidine, guanosine, or uridine at the corresponding site of the A20 of three mutant sarcin/ricin domain RNAs (Liu et al. 2002, 2017). 


\section{Gymnosperm RIP}

\section{Biota orientalis RNase}

The 13-kDa B. orientalis RNase (RNase Bo) from the mature cypress tree (Oriental arborvita) seeds produced cleavage of a phosphodiester linkage between C4453 and A4454 referred to as $B$. orientalis RNase region of 28S RNA in rat ribosomes in the presence of magnesium ions at a concentration of $25 \mathrm{mM}$. A small RNA-fragment called the S-fragment was generated and this action resembled that of $\alpha$-sarcin. The distance between the cleavage-site of $\alpha$-sarcin (G4325) was at a distance of 128 nucleotides away from that of B. orientalis RNase (C4453). The damaged ribosome failed to bind aminoacyl-transfer RNA (Xu et al. 2004; Liu et al. 2017).

\section{Flowering plant type III RIP}

\section{Maize RIP}

The active heterodimeric form of maize RIP was composed of a16.5-kDa chain and an 8.5$\mathrm{kDa}$ chain. It was derived from an inactive 34-kDa precursor exhibiting an isoelectric point of 6.5 , by removing from the center of the precursor, a 25-residue internal inactivation domain carrying a net charge of -6 , to yield a form exhibiting an isoelectric point above 9 and subsequent processing at the $\mathrm{C}$ and $\mathrm{N}$ terminals. This is a unique way of precursor processing since it usually involves cleavage at the $\mathrm{N}$ terminal (Walsh et al. 1991).

The susceptibility of maize ribosomes to pokeweed RIP was considerably higher than that to the precursor and active forms of maize RIP, indicating the precursor form of maize RIP does not serve as a protective device for shielding homologous ribosomes from attack by the active forms of maize RIP. The 25-amino acid inactivation region, and not the extensions at the $\mathrm{N}$ and C-terminals, mainly accounts for the inhibition of enzymatic activity in the precursor form of maize RIP. Elimination of all three aforementioned regions resulted in activity similar to the active form of maize RIP (Hey et al. 1995).

Recombinant maize proRIP1 (rproRIP1) was devoid of enzymatic activity against ribosomes of various species. Compared with an active deletion mutant of rproRIP1, rproRIP1 activated by papain expressed higher activity toward rabbit and Aspergillus flavus ribosomes, especially in the case of rabbit ribosomes. rproRIP1 activated by papain exhibited substantially higher activity toward rabbit ribosomes than maize ribosomes and was devoid of enzymatic activity toward E. coli ribosomes (Krawetz and Boston 2000).

Maize kernel ribosome-inactivating protein 1 (RIP1) but not RIP1 mutant protein devoid of ribosome-inactivating activity exerted a potent antiproliferative action on nonpathogenic Aspergillus nidulans hyphae. RIP1 induced hyphal branching in pathogenic A. flavus with only a single growing hyphal tip in one conidium. RIP1 inhibited the postdivisional growth stage in both A. nidulans and A. flavus (Nielsen et al. 2001).

Transgenic rice plants expressing both a modified maize RIP gene and a rice basic chitinase gene were more resistant to sheath blight fungus Rhizoctonia solani, but were protected from the fungi Bipolaris oryzae and Magnaporthe grisea (Kim et al. 2003). 
Transgenic tobacco (Nicotiana tabacum) plants overexpressing both activated maize RIP and tobacco anionic peroxidase which are resistance proteins were more resistant to feeding by larvae of the cigarette beetle Lasioderma serricorne and the corn earworm Helicoverpa zea and caused a higher larval death rate than wild-type tobacco plants (Dowd et al. 2006).

In addition to maize RIP1, there is a second maize RIP (RIP2), coded for by the gene Rip3:2. Rip3:2 RNA was found in low levels in leaves, shoots, roots, silks, and tassels. Distinct from the Rip3:1 gene, the Rip3:2 gene is not regulated by the transcriptional activator Opaque-2 but upregulated when there is drought. RIP2 resembles proRIP1 in general except for a 19-aminoacid internal portion of proRIP2 which bears little resemblance to proRIP1 other than abundance in acidic amino acids. Distinct regulation of Rip3:1 and Rip3:2 genes indicates that both RIP1 and RIP2 are defense proteins but RIP1 is regulated developmentally whereas RIP2 is influenced by the environment (Bass et al. 2004).

Crystals of the active form and the proenzyme form of maize RIP have been diffracted to 2.5 and 2.4 A, respectively, with main chain root mean square deviation (RMSD) of 0.519. In the proenzyme form, the 25-residue internal inactivation domain is located superficially and comprises a flexible loop succeeded by a long alpha-helix. Interaction of maize RIP with ribosome and its cytotoxicity, but not cellular uptake, was reduced in the presence of the internal inactivation domain. Maize ribosome-inactivating protein resembles its bacterial counterparts in lacking a back-up glutamate at the active site, which assists the protein to keep some residual activity in the event of a mutation of the catalytic glutamate. The structure disclosed that the active site is not large enough to house a pair of glutamate residues. The maize ribosome-inactivating protein may be an intermediate during the course of evolution RIPs (Mak et al. 2007).

During germination, proteolytic cleavage of the 25 -amino acid internal inactivation region leads to the formation of the active heterodimeric maize RIP for protection against invading organisms. HIV-1 protease-activated maize RIP variants produced in vitro manifested augmented $\mathrm{N}$-glycosidase activity and suppressive activity on p24 antigen production in HIV1-infected human T cells in comparison with maize RIP which had not been activated (Law et al. 2010).

Maize RIP is similar to type I RIPs and the A-chain of type II RIPs in protein structure in general. However, it differs from them in some areas such as shorter alphaB and beta 6 segments for facilitating substrate binding, and an alpha-helix in lieu of an antiparallel beta-sheet in the Cterminal region implicated in binding ribosomal protein P2 in certain RIPs. In addition there is relocation of $\mathrm{P} 2$ binding site to the $\mathrm{N}$-terminal region close to the internal inactivation domain due to changes in the electrostatic surface potential and three-dimensional structures on the protein (Yang et al. 2010).

Mature maize leaves expressing maize ribosome-inactivating protein and wheat germ agglutinin were more resistant to feeding by first-instar larvae of fall armyworms (Spodoptera 
frugiperda) and corn earworms ( $\mathrm{H}$. zea) and to Fusarium verticillioides. Maize ribosomeinactivating protein and wheat germ agglutinin neither synergized with nor antagonized one another in their anti-insect activity (Dowd et al. 2012).

Hydrophobic interaction of maize RIP with the 'FGLFD' motif of the ribosomal stalk protein P2 through Lys158-Lys161 found in the N-terminal region and at the base of its internal loop was attenuated compared with Shiga toxin $A$ and trichosanthin. The dissociation constants of the interaction were $195 \mu \mathrm{M}$ with Shiga toxin $\mathrm{A}, 612 \mu \mathrm{M}$ with trichosanthin and $1038 \mu \mathrm{M}$ with maize RIP, respectively. The cytotoxicity of maize RIP toward 293T cells and its ribosome depurinating activity were 10 times and 48 times lower than those of trichosanthin, respectively (Wong et al. 2012).

Maize ribosome-inactivating protein 2 (RIP2) is produced as an inactive precursor form which is proteolytically cleaved in the gut of fall armyworm (S. frugiperda) larvae to yield the active form. RIP2 is a defense protein which protects the maize plant from insects. Larval feeding, rather than mechanical wounding, brought about an excessive level of RIP2 in the leaves. Plant hormones such as abscisic acid, ethylene, and methyl jasmonate regulated the expression of RIP2 (Chuang et al. 2014).

Recombinant active maize RIP inhibited ex vivo lysis of macaque peripheral blood mononuclear cells which had been infected with chimeric simian-human immunodeficiency virus (SHIV) 89.6. The viral load in plasma was lowered transiently. Adverse changes in immune function and untoward side effects were indiscernible, rendering maize RIP a promising candidate for development into an anti-HIV therapeutic agent (Wang et al. 2015).

The two cereal RIPs, maize RIP1 and barley JIP60, and probably also sorghum RIP, differ from other plant RIPs because of their proteolytic activation mechanisms and absence of signal peptides. Cereal RIPs likely shield the plants from attack by insects and fungal pathogens and may play a role in abiotic stress response or senescence (De Zaeytijd and Van Damme 2017).

\section{Peptides derived from flowering plant type I RIP}

Peptides from leaves of type 1 RIP Phytolacca dioica

Peptide PDL440-65, derived by chemical fragmentation of P. dioica type 1 RIP PD-L4, was equipotent in antimicrobial activity to PD-L4 and elicited an immune response from human cells (Pizzo et al. 2015). The PD-L1/2-derived peptides IKY31 and IKY23 exerted activity against planktonic bacterial cells as well as bacterial biofilms. They displayed stable helical conformations when exposed to membrane-mimicking agents and beta structures when exposed to components of the bacterial cell wall. RIPs may serve as precursors of antimicrobial and anti-biofilm agents, which are produced by proteolytic action to act against pathogens (Pizzo et al. 2018). 


\section{Cinphorin}

Cinphorin is a small type II RIP from seeds of the camphor tree (Cinnamomum camphora). Following reduction, both cinphorin and cinnamomin demonstrated RNA N-glycosidase activity and translation inhibitory activity. The molecular weight and first ten $\mathrm{N}$-terminal amino acids of the $A$ and $B$ chains of cinphorin were identical to those of the type II RIP cinnamomin from the same seeds. The A chain of cinphorin possessed only half the molecular weight of the $A$ chain of cinnamomin although the B chains of cinphorin and cinnamomin were of the same size. Cinphorin mRNA was undetectable by Northern blotting and RT-PCR. Cinphorin may be a protein splicing product of cinnamomin (Hou et al. 2002).

\section{Small flowering plant RIPS}

Two 11-kDa wax gourd (Benincasa hispida) seed peptides, designated as alpha-and betabenincasins, both with an $\mathrm{N}$-terminal sequence enriched in arginine and glutamine residues, were purified using affinity chromatography on Affi-gel blue gel, cation-exchange chromatography on Mono S, and gel filtration on Superdex 75. Alpha-benincasin inhibited mycelial growth in the fungi Physalospora piricola and Coprinus comatus but was devoid of suppressive activity on Mycosphaerella arachidicola. It inhibited protein synthesis in the cellfree rabbit reticulocyte lysate system with an IC50 of 20 pM, more potently than betabenincasin $(\mathrm{IC} 50=320 \mathrm{pM})(\mathrm{Ng}$ et al. 2003a, b).

\section{Gamma-momorcharin}

This 11.5-kDa small RIP from bitter gourd (Momordica charantia) seeds enriched in arginine and glutamate/glutamine at its N-terminal manifested translation inhibitory activity with an IC50 of $55 \mathrm{nM}$ in the cell-free rabbit reticulocyte lysate system. Gamma-momorcharin acted on adenosine at position 4324 in a highly conserved loop of $28 \mathrm{~S}$ ribosomal RNA (Pu et al. 1996).

\section{Charantin}

The 9.7-kDa charantin from bitter gourd seeds, which manifested pronounced N-terminal sequence homology to the $7.8-\mathrm{kDa}$ bitter gourd napin-like peptide, inhibited cell-free protein synthesis in the rabbit reticulocyte lysate system with a higher IC50 (400 nM) than that of gamma-momorcharin $(55 \mathrm{nM})$. Results of the $\mathrm{N}$-glycosidase assay revealed the presence of charantin resulted in formation of a band similar to that formed by the small RIPs gammamomorcharin and luffin S (Parkash et al. 2002a, b).

Hispin

A 21-kDa RIP designated as hispin, manifesting $\mathrm{N}$-glycosidase and antifungal activities and a novel $\mathrm{N}$-terminal sequence, was isolated from hairy melon (Benincasa hispida var. chieh-gua) seeds. It exhibited cell-free translation inhibitory activity in the cell-free rabbit reticulocyte lysate system with an IC50 of $165 \mathrm{pM}$. The isolation protocol entailed affinity chromatography on Affigel blue gel and cation exchange chromatography on CM-Sepharose and Mono S ( $\mathrm{Ng}$ and Parkash 2002). 


\section{Lagenin}

The 20-kDa lagenin from bottle gourd (Lagenaria siceraria) seeds reduced cell-free protein synthesis in the cell-free rabbit reticulocyte lysate system with an IC50 of $0.21 \mathrm{nM}$ and catalyzed hydrolysis of yeast tRNA with an activity of $45 \mathrm{U} / \mathrm{mg}$. Its $\mathrm{N}$-terminal sequence showed differences from counterparts in Family Cucurbitaceae, including elimination of the first three residues and a substitution of the 4th (Phe), 17th (Phe), 18th (Ile), and 22nd (Arg) amino acids invariant in other RIPs. The protein was unbound on DEAE-cellulose, but bound on Affi-gel blue gel as well as CM-Sepharose CL-6B (Wang and Ng 2000a, b).

\section{Luffin-S}

This small RIP from sponge gourd (Luffa cylindrica) seeds had a molecular weight of about 10 $\mathrm{kDa}$, much smaller than those of the homologous RIPS luffin-a (27 kDa) and luffin-b (28 kDa). It displayed an alpha-sarcin-like mechanism on ribosomal RNA and translation inhibitory activity analogous to trichosanthin (Gao et al. 1994).

\section{Luffacylin}

The 7.8-kDa luffacylin from sponge gourd seeds was an RNA N-glycosidase that suppressed protein synthesis in the cell-free rabbit reticulocyte lysate with an IC50 of $140 \mathrm{pM}$. Its N-terminal sequence showed pronounced homology to that of the $6.5-\mathrm{kDa}$ sponge gourd arginineglutamate rich seed polypeptide. Luffacylin impeded mycelial growth in $\mathrm{M}$. arachidicola and Fusarium oxysporum (Parkash et al. 2002a).

\section{Luffin P1}

The 5226-Da luffin P1 exhibited RNA N-glycosidase activity and hence suppressed protein synthesis in the cell-free rabbit reticulocyte lysate system with an IC50 of $0.88 \mathrm{nM}$. Conversion of luffin P1 to a polymer enhanced its rRNA N-glycosidase activity (Li et al. 2003a, b, c). Luffin $\mathrm{P} 1$ demonstrated a mechanism dissimilar from the N-glycosidase activity of other RIPs. It is probably associated with charge complementation with viral or cellular proteins $(\mathrm{Ng}$ et al. 2011).

The isolation procedure of luffin $\mathrm{P} 1$ involved ammonium sulfate precipitation, cation exchange chromatography on CM-cellulose 52, affinity chromatography on Blue-gel and FPLC-cation exchange chromatography on Mono $\mathrm{S}$. The sequence of the first eleven $\mathrm{N}$-terminal amino acids was the same as the N-terminal sequence (from G3 to R13) of 6.5-kDa Arg/Glu-rich Luffa cylindrica seed peptide. Luffin $\mathrm{P} 1$ also showed pronounced sequence resemblance to pumpkin seed trypsin inhibitor $\mathrm{C} 2$ peptide. Luffin $\mathrm{P} 1$ suppressed trypsin activity and translation in the cell-free rabbit reticulocyte lysate system with an IC50 of $22 \mu \mathrm{M}$ and $0.6 \mathrm{nM}$, respectively (Li et al. 2003a, b, c).

Recombinant human interleukin-2-luffin P1 (hlL-2-luffin P1) immunotoxin suppressed T cell proliferation in mixed lymphocyte reaction and response to the mitogen Concanavalin $A$ with an IC50 of 1.8-10 nM. hIL-2-luffin P1 extended the survival time of animals bearing major histocompatibility complex-mismatched skin and kidney allografts (Wang et al. 2010). 
Luffin P1 was fused to the C-terminal of an antibody against epidermal growth factor receptor (EGFR). The recombinant protein was expressed in E. coli, refolded and fractionated using immobilized nickel-affinity chromatography. The protein demonstrated specific binding and pronounced cytotoxicity to EGFR-positive cancer cells such as U251 cells, but manifested virtually no binding to EGFR-negative cells such as Jurkat cells (Ma et al. 2012).

\section{Luffangulin}

The 5.6-kDa luffangulin from Luffa acutangula seeds, with an arginine/glutamate-rich $\mathrm{N}$ terminal sequence, suppressed protein synthesis in the cell-free rabbit reticulocyte lysate system with an IC50 of $3.5 \mathrm{nM}$, but it was devoid of HIV-1 reverse transcriptase inhibitory activity (Wang and $\mathrm{Ng} 2002$ ).

\section{Cucurmoschin}

The 8-kDa peptide from black pumpkin seeds, with an abundance of arginine, glycine, and glutamate at the $\mathrm{N}$-terminal, manifested antifungal activity toward $\mathrm{F}$. oxysporum, Botrytis cinerea, and M. oxysporum. The peptide suppressed protein synthesis in the cell-free rabbit reticulocyte lysate system with an IC50 of $1.2 \mu \mathrm{M}$. Like the vast majority of RIPs, it was bound on Affi-gel blue gel but not on DEAE-cellulose (Wang and $\mathrm{Ng} 2003$ ).

\section{Moschins}

From fresh brown pumpkin (Cucurbita moschata) seeds, two 12-kDa proteins designated alpha-moschin and beta-moschin characterized by an N-terminal sequence containing an abundance of arginine and glutamate residues were reported. The N-terminal sequences of alpha- and beta-moschins displayed pronounced homology to Drosophila apoptosis gene product and prepro 2S albumin, respectively. Alpha- and beta-moschins exhibited cell-free translation inhibitory activity in the cell-free rabbit reticulocyte lysate system with an IC50 of 17 $\mu \mathrm{M}$ and $300 \mathrm{nM}$, respectively ( $\mathrm{Ng}$ et al. 2002).

\section{Pisavins}

Alpha- and beta-pisavins, two ribosome-inactivating proteins designated from garden pea (Pisum sativum var. arvense Poir) seeds with $\mathrm{N}$-terminal amino acid sequence identity, differed in molecular weight, $20.5 \mathrm{kDa}$ and $18.7 \mathrm{kDa}$, respectively. Merging of the two proteins into a single band with an isoelectric point exceeding 9.3 was observed in isoelectric focusing. Both suppressed cell-free translation in the rabbit reticulocyte lysate system with an IC50 close to $0.5 \mathrm{nM}$ and displayed RNase activity toward transfer RNA and N-glycosidase activity toward ribosomal RNA to produce an Endo's fragment. Circular DNA and supercoiled DNA were transformed, in the presence of the pisavins, into a linear form (Lam et al. 1998).

\section{S-trichokirin}


The 8-kDa strongly basic RNA N-glycosidase from Trichosanthes kirilowii seeds, designated as S-trichokirin which is a basic protein with a pl near $\mathrm{pH}$ 9, demonstrated RNA N-glycosidase activity and suppressed protein biosynthesis in the cell-free rabbit reticulocyte lysate system with an IC50 of $0.115 \mathrm{nM}$. Its isolation procedure involved ammonium sulfate precipitation, cation exchange chromatography on CM-52, gel filtration on Sephacryl S-100 and FPLC-cation exchange chromatography on Mono S (Tai et al. 2000).

\section{Trichokirin-S1}

Trichokirin-S1, an 11.426-kDa rRNA N-glycosidase from T. kirilowii seeds, manifested translation inhibitory activity in the cell-free rabbit reticulocyte lysate system with an IC50 of $0.7 \mathrm{nM}$ (Li et al. 2003a, b, c).

\section{Trichosanthrip}

Trichosanthrip from mature T. kirilowii seeds, which exhibited a molecular weight of 10.965$\mathrm{kDa}$, impeded protein synthesis in the cell-free rabbit reticulocyte lysate system with an IC50 of about $0.15 \mathrm{nM}$ and demonstrated N-glycosidase activity toward 28 S rRNA (Shu et al. 2009).

\section{Mushroom type II RIP}

\section{Polyporus umbellatus type II RIP}

A gene cloned from P. umbellatus sclerotia by RT-PCR encoded a 32.33-kDa type IIRIP with an isoelectric point of 5.58. The RIP contained conserved domains of RICIN superfamily protein. It bore a relationship to Marasmius oreades RIP. The gene of P. umbellatus RIP was expressed in a variety of tissues of the mushroom examined. Upregulation of the gene was observed in the Armillaria mellea-infected parts of the mushroom (Liu et al. 2017).

\section{Mushroom RIPs \\ Calcaelin}

Calcaelin from fresh fruiting bodies of the mosaic puffball mushroom Calvatia caelata was bound on Affi-gel blue gel and unbound on DEAE-cellulose. It was a 39-kDa protein composed of a $19-\mathrm{kDa}$ subunit and a $20-\mathrm{kDa}$ subunit. The two subunits were identical in $\mathrm{N}$-terminal amino acid sequence which partially resembled plant RIPs and exhibited weaker similarity to the fungal ribosome-inactivating proteins restrictocin and alpha-sarcin. Calcaelin suppressed protein synthesis in the cell-free rabbit reticulocyte lysate with an IC50 value of $4 \mathrm{nM}$. Calcaelin exhibited antiproliferative activity toward breast cancer cells, antimitogenic activity toward mouse splenocytes, and RNase activity of $1.58 \mathrm{U} / \mathrm{mg}$ toward yeast tRNA ( $\mathrm{Ng}$ et al. 2003a, b).

Flammulin, flammin, velin, and velutin

Flammulin from fruiting bodies of the golden needle mushroom Flammulina velutipes displayed a molecular weight of $40 \mathrm{kDa}$, and an $\mathrm{N}$-terminal sequence analogous to those of plant RIPs. The protocol for its purification involved anion exchange chromatography on DEAE-cellulose, cation exchange chromatography on SP-Sepharose, and affinity chromatography on Affi-gel 
blue gel. Flammulin was unbound on the weak anion exchanger DEAE-cellulose at neutral pH and low ionic strength but bound on the weak cation exchanger CM-Sepharose and the affinity chromatographic media Affi-gel blue gel under similar conditions. Flammulin suppressed protein synthesis in a cell-free rabbit reticulocyte lysate system with an IC50 of $0.25 \mathrm{nM}$ (Wang and $\mathrm{Ng} 2000 \mathrm{a}, \mathrm{b})$.

Velutin from F. velutipes possessed a low molecular weight of $13.8 \mathrm{kDa}$ and an N-terminal sequence with some resemblance to those of plant RIPs. The protocol for its purification involved chromatography on the anion exchanger DEAE-cellulose, chromatography on the strong cation exchanger SP-Sepharose, and finally affinity chromatography on Affi-gel blue gel. Velutin exhibited inhibitory activity toward human immunodeficiency virus type 1(HIV-1)

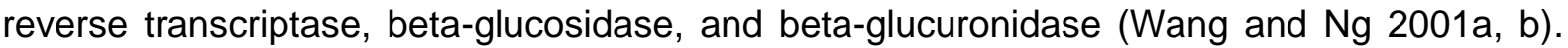
Glucosidases facilitate HIV gp120 glycosylation. Glycohydrolase inhibition reduces HIV infectivity (Collins and Ng 1997; Collins et al. 1997).

Flammin and velin from F. velutipes fruiting bodies displayed a molecular mass of $30 \mathrm{kDa}$ and $19 \mathrm{kDa}$, respectively. Although both of them were unbound on DEAE-cellulose and bound on Affi-gel blue gel and CM-Sepharose, they could be separated by fast protein liquid chromatography-gel filtration on Superdex 75 . Flammin exhibited only slight $\mathrm{N}$-terminal sequence homology to angiosperm type 1 RIPs such as alpha-momorcharin, betamomorcharin, and trichosanthin, but did not resemble other mushroom RIPs. Velin showed some similarity to the A chain of abrin, a type 2 RIP. Flammin and velin repressed protein synthesis in the cell-free rabbit reticulocyte lysate system with an IC50 of $1.4 \mathrm{nM}$ and $2.5 \mathrm{nM}$, respectively. Neither of them exhibited protease or ribonuclease activity ( $\mathrm{Ng}$ and Wang 2004).

\section{Hypsin}

Hypsin is a 20-kDa RIP from fruiting bodies of the mushroom Hypsizigus marmoreus. The protocol for its purification involved cation exchange chromatography on CM-cellulose, affinity chromatography on Affi-gel Blue Gel, and finally chromatography on the strong anion exchanger Mono Q. It inhibited protein synthesis in cell-free rabbit reticulocyte lysate, HIV-1 reverse transcriptase activity, and thymidine uptake by murine splenocytes with an IC50 of 7 $\mathrm{nM}, 7 \mathrm{nM}$, and $1 \mu \mathrm{M}$, respectively. Hypsin exhibited antifungal activity toward B. cinerea, $\mathrm{F}$. oxysporum, M. arachidicola, and P. piricola, with an IC50 of 0.06, 14.2, 2.7, and $2.5 \mu \mathrm{M}$, respectively. It inhibited protein synthesis in cell-free rabbit reticulocyte lysate and HIV-1 reverse transcriptase activity, with an IC50 of $7 \mathrm{nM}$ and $8 \mu \mathrm{M}$, respectively. The protein synthesis inhibitory activity was relatively thermostable and trypsin-stable as approximately $60 \%$ of the inhibitory activity remained following exposure to the boiling temperature for $10 \mathrm{~min}$ and $100 \%$ activity was recovered after trypsin treatment for a short duration. Hypsin inhibited proliferation of human leukemia and hepatoma cells and mouse leukemia cells (Lam and $\mathrm{Ng}$ 2001a, b).

Hypsin from $\mathrm{H}$. mamoreus at $2.5 \mu \mathrm{M}$ elicited a dose-dependent deranged development in cultured murine embryos during the organogenesis period from E8.5 to E9.5. A reduction in the final somite number, and an increase in structural abnormalities such as a patent cranial neural tube, aberrant branchial arches, lack of forelimb buds and a twisted body axis, were observed. Nevertheless, the otic and optic placodes were affected to a lesser extent. Hypsin 
also cause more cell death. In stark contrast, velutin did not have any teratogenic effects on mouse embryos ( $\mathrm{Ng}$ et al. 2010).

\section{Marmorin}

Marmorin from fresh fruiting bodies of the mushroom $\mathrm{H}$. marmoreus displayed a novel $\mathrm{N}$ terminal sequence and a molecular weight of $9.567 \mathrm{kDa}$. It was purified by ion exchange chromatography on DEAE-cellulose, affinity chromatography on Affi-gel blue gel, and gel filtration on Superdex 75. Marmorin was not bound on DEAE-cellulose but was bound on Affigel blue gel. Marmorin exhibited antiproliferative activity toward breast cancer MCF-7 cells with an IC50 of $5 \mu \mathrm{M}$, hepatoma Hep G2 cells with an IC50 of $0.15 \mu \mathrm{M}$, RIPs from bitter gourd, garden pea, hairy gourd, ridge gourd, and the mushroom F. velutipes. Marmorin inhibited protein synthesis in the cell-free rabbit reticulocyte lysate system and HIV-1 reverse transcriptase activity with an IC50 of $0.7 \mathrm{nM}$ and $30 \mu \mathrm{M}$, respectively. Marmorin was lacking in RNase, protease, trypsin inhibitory, hemagglutinating, mitogenic, anti-mitogenic, nitric oxideinducing, and antifungal activities (Wong et al. 2008).

Marmorin reduced the survival of breast cancer in vitro and in vivo. Estrogen receptor (ER)positive MCF7 breast cancer cells were more responsive than ER-negative MDA-MB-231 cells to marmorin. Estrogen receptor $\alpha(E R \alpha)$ expression was attenuated, and $17 \beta$-estradiol-induced proliferation of MCF7 cells was suppressed by marmorin. ERa knockdown in MCF7 cells led to a decrement in the antiproliferative potency of marmorin, signifying the involvement of the ERa-mediated pathway in the activity of marmorin on ER-positive breast cancer cells. Apoptoses in both MCF7 and MDA-MB-231 cells were brought about by marmorin in a timedependent manner. Activation of caspase- 9 in the breast cancer cells, depolarization of their mitochondrial membrane potential, and arrest of the breast cancer cells in the G2/M-phase, took place in MCF7 cells and to a less pronounced way in MDA-MB-231 cells in response to marmorin. In addition, in both MCF7 and MDA-MB-231 cells, marmorin activated the death receptor apoptotic pathway (through caspase-8 activation) and endoplasmic reticulum stress (through PERK and IRE1 $\alpha$ phosphorylation, caspase-12 cleavage and $\mathrm{CHOP}$ expression upregulation).

\section{Lyophyllin}

Lyophyllin from fruiting bodies of the mushroom Lyophyllum shimeji possessed a molecular weight of $20 \mathrm{kDa}$ and an N-terminal sequence resembling those of angiosperm RIPs. It exerted an antifungal action against $\mathrm{C}$. comatus and P. piricola $(\mathrm{IC} 50=2.5 \mu \mathrm{M})$. Lyophyllin and the antifungal protein from $L$. shimeji synergized in their action against the fungus $P$. piricola. The protocol for its purification involved cation exchange chromatography on CM-cellulose, affinity chromatography on Affi-gel Blue Gel, and finally cation exchange chromatography on Mono S. It inhibited protein synthesis in the cell-free rabbit reticulocyte lysate, HIV-1 reverse transcriptase activity, and thymidine uptake by murine splenocytes with an IC50 of $1 \mathrm{nM}, 7.9$ $\mathrm{nM}$, and $1 \mu \mathrm{M}$, respectively. Lyophyllin did not have hemagglutinating or ribonuclease activity (Lam and $\mathrm{Ng} 2001 \mathrm{a}, \mathrm{b}$ ).

Lyophyllin microinjected at a concentration as low as $50 \mu \mathrm{g} / \mathrm{ml}$ into cultured postimplantation mouse embryos during the period of organogenesis from E8.5 to E9.5 produced dose- 
dependent abnormalities. The affected embryonic structures adversely affected by lyophyllin comprised the body axis, the final somite number, cranial neural tube, branchial arches, and forelimb buds. The otic and optic placodes were more recaltrant. Forebrain blisters within the cranial mesenchyme were observed at lyophyllin doses above $500 \mu \mathrm{g} / \mathrm{ml}$. Histologically observed cell death rose concurrently with the increased appearance of abnormal structures (Chan et al. 2010).

\section{Pleuturegin}

Pleuturegin from fresh sclerotia of the mushroom Pleurotus tuber-regium differed from the bulk of plant and mushroom RIPs in its adsorption on DEAE-cellulose and unadsorption on SPSepharose, but like other RIPs it was adsorbed on Affi-gel blue gel. Its N-terminal sequence did not share similarity with other mushroom RIPs including flammulin, hypsin, lyophyllin, and velutin. It had a larger molecular weight $(38 \mathrm{kDa}$ ) than those of hypsin and lyophyllin (both 20 $\mathrm{kDa})$ and velutin $(13.8 \mathrm{kDa})$ but resembled flammulin $(40 \mathrm{kDa})$ in molecular weight. Pleuturegin was lacking in ribonuclease activity. It suppressed protein synthesis in a cell-free rabbit reticulocyte lysate system with an IC50 of $0.5 \mathrm{nM}$ (Wang and $\mathrm{Ng} \mathrm{2001a,} \mathrm{b).}$

\section{Bacterial RIPs}

\section{Shiga toxin}

Shiga toxins are bacterial proteins produced by Shigella dysenteriae and some E. coli strains. They are bacterial type 2 RIPs with an AB5 structure composed of a catalytic N-glycosidase A chain (which depurinates a universally conserved adenine residue in the $\alpha$-sarcin/ricin loop of the $28 \mathrm{~S}$ ribosomal RNA) and five identical $B$ chains and bind to the target cells with specific sugars. Gb3 receptors on the brain, intestinal, and renal cells recognize Shiga toxins and are damaged by the toxins (Chan and $\mathrm{Ng} \mathrm{2016).} \mathrm{Severe} \mathrm{Shiga} \mathrm{toxin} \mathrm{intoxication} \mathrm{results} \mathrm{in}$ hemolytic-uremic syndrome, which may lead to renal failure and death. Production of recombinant Shiga toxin from non-toxic recombinant Shiga toxin A subunit and recombinant Shiga toxin B subunits allows screening and assessment of inhibitors of a small size for development of therapeutic agents (Chauhan et al. 2019). Shiga toxin producing E. coli O157:H7 causes food-poisoning. Some of these strains secrete Shiga toxin 1 and/or Shiga toxin 2 or variants which cause hemolytic uremic syndrome or hemorrhagic colitis. The strains producing Shiga toxin 2 have greater virulence and connection with hemolytic-uremic syndrome. Shiga toxins 1 and 2 exhibit differences in structure, receptor binding, dependence on ribosomal proteins, and pathogenicity. The B subunit and perhaps the A1 subunit as well may contribute to the dissimilar toxicities of Shiga toxins 1 and 2 (Basu and Tumer 2015).

Shiga toxins and the toxic plant type II RIP ricin trigger apoptotic cell death in myeloid, lymphoid endothelial and epithelial cells in vitro, and in a number of organs. There may be dissociation between apoptosis and suppression of protein synthesis brought about by ricin and Shiga toxins. The B chain of ricin and B subunits of Shiga toxin upregulate both the death receptormediated (extrinsic) and mitochondrial-mediated (intrinsic) pathways of apoptosis induction in some types of cells (Tesh 2012a, b). 
Shiga toxins upregulate different pathways connected with stress. Subsequent to depurination in the $\alpha$-sarcin/ricin loop of eukaryotic ribosomes, the ribotoxic stress response and thus the mitogen-activated protein kinase (MAPK) cascade is triggered signaling through MAPK cascades, which in turn activates innate immunity and controls apoptosis. Shiga toxin unfolding within the endoplasmic reticulum may initiate the unfolded protein response which is continued by formation of truncated, misfolded proteins. Treatment to prevent damage produced by Shiga toxin and progression of disease may be facilitated by targeting sites on the stress response pathways (Tesh $2012 \mathrm{a}, \mathrm{b}$ ).

\section{Streptomyces coelicolor RIP}

RIP-like proteins similar to plant type I RIPs rather than the RIP subunit (Shiga toxin A) of Shiga toxin were found in the genomes of two actinomycete bacteria. RIP-like proteins similar to Shiga toxin A were noted in the genomes of $\beta$ - and $\gamma$-protebacteria The 30-kDa RIP-like gene product SCO7092 from the Gram-positive soil bacterium Streptomyces coelicolor (RIPSc) was an N-glycosidase. Excessive formation of RIPsc in E. coli and Streptomyces lividans seriously retarded growth. S. coelicolor RIP suppressed protein synthesis in a cell-free system but failed to inhibit fungal and bacterial cells owing to inability to enter the cells (Reyes et al. 2010).

\section{Spiroplasma RIP}

The fruitfly Drosophila neotestacea is protected against infection caused by the nematode parasite Howardula aoronymphium with the assistance of its symbiotic bacterium Spiroplasma. Spiroplasma produces an RIP similar to E. coli Shiga-like toxins and depurinates H. aoronymphium ribosomal RNA. Recombinant Spiroplasma RIP catalyzes the cleavage of purine from 28S rRNA and also from Howardula rRNA at the target site of RIPs within the $\alpha-$ sarcin/ricin loop of 28S rRNA without affecting fruitfly 28S rRNA (Hamilton et al. 2016).

Out of the several RIP genes in the genome of Spiroplasma poulsonii, SpRIP1 and SpRIP2 are the only RIPs expressed throughout the life cycle of the fruitfly. SpRIP1 and 2 expression in uninfected flies brought about a shortening of fruitfly lifespan and hemocyte count and increase embryonic mortality (Garcia-Arraez et al. 2019).

Various Spiroplasma strains, which comprise the male-killing symbiont (sMel) of D. melanogaster, are protective against parasitic wasps, but only the sNeo strain which produces infections in D. neotestacea is protective against nematode parasites. The RIP determines whether there is protective activity against nematodes. RIPs of the sMel Spiroplasma strain are devoid of inhibitory activity toward nematode ribosomes in vivo (Ballinger et al. 2019). A Spiroplasma strain which infects a mycophagous phorid fly Megaselia nigra was found. The M. nigra symbiont codes for different RIPs which comprise plasmid-encoded toxins with close relationship to sNeo RIPs (Ballinger et al. 2019).

Mateos et al. (2019) conducted a study to ascertain whether inheritable endosymbionts which gave rise to different $D$. melanogaster reproductive phenotypes affected the mRNA transcriptome of early embryos. mRNA-seq was employed to assess differential expression in 
Drosophila embryos devoid of endosymbionts (control) in comparison with those containing S. poulsonii strain Hyd1 which is a strain naturally associated with Drosophila hydei and devoid of a reproductive phenotype; the male-killing S. poulsonii strain MSRO-Br; and the cytoplasmic incompatibility-inducing Wolbachia strain wMel. No effect of the symbiont was detected on mRNA composition of early embryos, indicating that the mechanism of reproductive manipulation does not entail changes of maternally loaded transcripts. mRNA-seq datasets from D.melanogaster embryos infected with Spiroplasma were used to look for rRNA depurination signals. Signals of rRNA depurination with slightly greater intensity were detected in treatment with male-killing S. poulsonii strain MSRO-Br than those from treatment with $\mathrm{S}$. poulsonii strain Hyd1, but signals were not detected in the symbiont-free control or treatment with the cytoplasmic incompatibility-inducing Wolbachia strain wMel, in keeping with the RIP action and mortality of male embryos caused by RIP (Mateos et al. 2019).

\section{Phylogenetic distribution of RIPs}

RIPs show a wide distribution in plants and in a few bacterial, fungal and metazoan species, suggesting an ancestral RIP domain in plants subsequently acquired by bacteria via horizontal gene transfer. This observation, together with sequence and phylogenetic analyses, prompted Lapadula et al. (2013) to put forward a hypothesis of the origin and evolution of the RIP domain, which suggested existence of several paralogous RIP genes prior to evolution of the three domains of life, in keeping with the contemporary concept of the Last Universal Common Ancestor (LUCA) as a complex, genetically redundant organism. Differential loss of paralogs in LUCA descendants, instead of multiple horizontal gene transfer events, may explain the complex pattern of RIP genes across existing species, as seen in other genes.

\section{Activation of RIPs}

The mechanisms involved in the activation of cereal RIPs comprise cleavage of internal peptides from the N-glycosidase domains of the RIPs by proteases (Bass et al. 2004; De Zaeytijd and Van Damme 2017). Reductive cleavage of the RIP A-chain of type II RIPs like ricin from the cell-binding $B$ chain, catalyzed by oxidoreductases such as protein disulfide isomerase and TMX (a transmembrane thioredoxin-related protein in the protein disulfide isomerase family) in the endoplasmic reticulum lumen, plays a role in the activation of ricin. DU145 prostatic cells in which TMX has been silenced exhibited diminished susceptibility to ricin. In contrast, exposure of lung cancer A549 cells control cells to Pseudomonas exotoxin A or saporin whose activation mechanism is only partly related and unrelated to reduction, respectively, did not lead to differences in cytotoxicity (Pasetto et al. 2012).

\section{Entry to cells}

Ricin dimers gain entry to target mammalian cells through receptor-mediated endocytosis. Saporin shows binding in vitro to alpha2-macroglobulin receptor/low-density lipoprotein receptor-related protein (LRP1) which mediates saporin internalization in human monocytes and in fibroblasts (De Virgilio et al. 2010). 
Treatment of eukaryotic ribosomes with plant RIPs proteins sensitized the 28S rRNA of eukaryotic ribosomes to aniline treatment, resulting in breakage of the $\mathrm{N}$-glycosidic bond at $\mathrm{A}$ 4324 in the highly conserved sarcin/ricin domain loop of $28 \mathrm{~S}$ rRNA and production of an RNA fragment consisting of approximately 450 nucleotides known as the Endo's band (Endo et al. 1988). The type I RIP trichosanthin and type II RIP cinnamomin produced the Endo's band and impeded protein synthesis (Liu et al. 2017). On the other hand, B. orientalis RNase broke a specific phosphodiester bond between C4453 and A4454 of 28SRNA and generated a small RNA-fragment (S-fragment) hence halting protein synthesis. The kelp RIP lamjapin also hydrolyzed 28S RNA to produce an RNA fragment smaller than the diagnostic R-fragment (Liu et al. 2017).

\section{Settings}

\section{Assays of activity of RIPS}

Advantages and the disadvantages of the assays of activity of RIPS including depurination assays (aniline cleavage assay, primer extension assay, qRT-PCR assay, adenine detection assay, enzymatically coupled adenine detection assay) and translation inhibition assays (in vitro translation inhibition assay, in-cell radioactive amino acid incorporation assay, in-cell luciferase synthesis assay, cell-based luciferase assay, in-cell GFP synthesis assay) have been evaluated by Zhou et al. (2018).

\section{Conclusion}

Single-chained type I RIPs may be found together with double-chained type II RIPs in the same plant (de Benito et al. 1995; Fong et al. 1996; Ling and Liu 1996; Fang et al. 2012). It is noted that small RIPs may coexist with regular-sized RIPs in the same plant, such as alphamomorcharin, beta-momorcharin, gamma momorcharin, and charantin in bitter gourd (M. charantia) seeds; alpha-and beta-kirilowins (Dong et al. 1994; Wong et al. 1996), S-trichokirin (Tai et al. 2000), trichokirin-S1 (Li et al. 2003a, b, c), and trichosanthrip (Shu et al. 2009) in T. kirilowii seeds; luffin-a, luffin-b, luffin-S, luffin $\mathrm{P}$, and luffacylin in sponge gourd (L. cylindrica) seeds; luffaculin and luffangulin in ridge gourd (L.acutangula) seeds; and C. moschata RIP, cucurmoschin and moschins in pumpkin (C. moschata) seeds. Nevertheless, the small RIPs hispidin, lagenin, benincasins, and pisavins are found in the absence of regular RIPs in seeds of hairy gourd (B. hispida var. chieh qua), bottle gourd (L. siceraria), wax gourd (B. hispida), and garden pea (P. sativum). Only regular-sized RIPs are found in some seeds. Overall speaking, issues of some plant show presence of both regular-sized (RIPs and small RIPs, while other plants show presence of only small RIPs or only regular-sized RIPs (Tables 1 and 2).

Table 1 RIPs covered in this review with their molecular weights and IC50s in translation in rabbit reticulocyte lysate

Full size table

Table 2 Presence of regular-sized ribosome-inactivating proteins (RIPs) alone, small RIPs alone, and concurrent existence in plant tissues

Full size table 
As judged from the complete amino acid sequences of the regular-sized RIPs and the partial sequences of the homologous small RIPs, the latter RIPs are not derived from the former RIPs. Chromatographic behavior of the vast majority of regular-sized RIPs resembles that of small RIPs in adsorption on cationic exchangers such as CM-cellulose/Mono $S$ and the affinity chromatographic media Blue-Sepharose or Affi-gel blue gel and non-adsorption on anionic exchangers such as DEAE-cellulose ( $\mathrm{Ng}$ et al. 1992; Fong et al. 1996; Wang and $\mathrm{Ng}$ Wang and Ng 2000a, b, 2001a, b, Wang et al. 2012; Li et al. 2003a, b, c). Small plant RIPs can be readily separated from the regular-sized counterparts by chromatography (Wang and $\mathrm{Ng}$ 2003).

RIPs manifest an array of molecular weights and amino acid sequences. It is known that proteins with similar functions may differ appreciably in structural characteristics such as molecular weight and amino acid sequence. This is amply exemplified by milk proteins and derived peptides; antifungal, antibacterial, and antiviral proteins/peptides produced by different organisms; and animal and plant hemagglutinins/lectins. Furthermore, different mechanisms may be employed to elicit the same activity (Wong et al. 2010; Cheung et al. 2014; $\mathrm{Ng}$ et al. 2015, 2016; Yan et al. 2015; Lam and Ng 2011; Lönnerdal et al. 2017; Shafee et al. 2017; Sierra et al. 2017; Neshani et al. 2019;Wong et al. 2019). Plant RIPs recognize a universally conserved $\alpha$-sarcin/ricin loop in rRNA and remove a single adenine (A4324 in $28 \mathrm{~S}$ rat rRNA), thereby halting protein synthesis and eliciting death in mammalian cells (Fabbrini et al. 2017). Small plant RIPs have also demonstrated similar N-glycosidase activity (Pu et al. 1996; Lam et al. 1998; Tai et al. 2000; Parkash et al. 2002a, b; Li et al. 2003a, b, c; Shu et al. 2009). Spiroplasma RIP catalyzes the splitting of purine from 28S rRNA and also from Howardula rRNA at the target site of RIPs within the $\alpha$-sarcin/ricin loop of 28S rRNA without affecting fruitfly $28 \mathrm{~S}$ rRNA (Hamilton et al. 2016). The catalytic N-glycosidase A chain of Shiga toxins also eliminates a conserved adenine residue in the $\alpha$-sarcin/ricin loop of the $28 \mathrm{~S}$ ribosomal RNA (Chan and $\mathrm{Ng} \mathrm{2016).} \mathrm{The} \mathrm{13-kDa} \mathrm{B.} \mathrm{orientalis} \mathrm{RNase} \mathrm{(RNase} \mathrm{Bo)} \mathrm{cleaves} \mathrm{a}$ phosphodiester linkage located between $\mathrm{C} 4453$ and $\mathrm{A} 4454$ referred to as $\mathrm{B}$. orientalis RNase region of $28 \mathrm{~S} R N A$ in rat ribosomes in the presence of $25 \mathrm{mM}$ magnesium ions. A small RNAfragment designated as the $S$-fragment is generated and this action resembles that of $\alpha$-sarcin. The cleavage-site of $\alpha$-sarcin (G4325) is separated by 128 nucleotides from that of $B$. orientalis RNase (C4453). The damaged ribosome is incapable of binding aminoacyl-transfer RNA (Xu et al. 2004; Liu et al. 2017).

RIPs have HIV enzyme inhibitory, antiviral, antifungal, antibacterial, anti-insect, antiprotozoal, and anticancer activities (Wong et al. 2010; Wang et al. 2012; Akkouh et al. 2015; Bolognesi et al. 2016; Ng et al. 1992, 2015, 2016; Zhu et al. 2018; Alves de Vasconcelos et al. 2018) and have potential applications in medicine and agriculture. Plant RIPs act against a variety of viruses including human immunodeficiency virus, hepatitis $B$ virus, and herpes simplex virus. A mechanism of antiviral activity may involve inactivation of host ribosome, inhibition of viral protein synthesis and host cell death. (Kaur et al. 2011). Regular-sized RIPs express antiproliferative activity toward cancer cells and anticancer activity toward tumor bearing mice (Zeng et al. 2015). RIPs trigger apoptosis in cancer cells through mitochondrial, death receptor, and endoplasmic reticulum pathways (Zeng et al. 2015). Small RIPs from plants also demonstrate antifungal (Wang and Ng 2001a, b; Ng et al. 2002; Parkash et al. 2002a, b; Ng et al. 2003a, b), and HIV-I reverse transcriptase inhibitory activity (Wang and $\mathrm{Ng}$ 2003). Small RIPs from mushrooms display antifungal, anticancer, and HIV-I reverse transcriptase inhibitory activities (Lam and Ng 2001a, b; Wang and Ng 2001a, b; Wong et al. 2008; Pan et al. 2013). 
Fungal ribotoxins have anti-insect (Dowd et al. 2012; Chuang et al. 2014) and anti-HIV activities (Yadav and Batra 2015).

Immunotoxins based on RIPs have anticancer activity (Polito et al. 2011). Molecular cloning of RIPs, expression and purification of recombinant RIP have been reported (Wang et al. 2012). Immunotoxins have also reported based on Sambucus type 2 RIPs which are nontoxic because of an intracellular pathway not leading to contact with ribosomes (Ferreras et al. 2011). Methods have been proposed to enhance the clinical usefulness of saporin-based immunotoxins including combinatorial strategies to promote RIP escape into the cytoplasm and genetic manipulations to reduce undesirable events like vascular-leak syndrome or identify T/B cell epitopes to mitigate immunogenicity (Giansanti et al. 2018). Many eminent scientists have contributed to the voluminous literature on RIPs, one of whom is Professor Fiorenzo Stirpe (Bolognesi et al. 2017). Immunotoxins based on small RIPs like trichokirin-S have been proposed (Li et al. 2003a, b, c).

The mushroom RIPs lyophyllin and hypsin displayed teratogenic effects on cultured mouse embryos. Straw mushroom RIP volvarin exhibited abortifacient activity in pregnant mice. The findings are in keeping with observations on regular RIPs including momorcharins, trichosanthin, and luffins. However, the small plant RIPs have not been so tested.

Only recently have RIPs been found in invertebrate animals (Lapadula et al. 2017). To date no vertebrate RIPs have been reported. In view of the myriad of invertebrate and vertebrate species in the animal kingdom, it is likely that many other animal RIPs remain to be uncovered. Delving into the roles of animal RIPs is undoubtedly a worthwhile undertaking.

\section{References}

Akkouh O, Ng TB, Cheung RC, Wong JH, Pan W, Ng CC, Sha O, Shaw PC, Chan WY (2015) Biological activities of ribosome-inactivating proteins and their possible applications as antimicrobial, anticancer, and anti-pest agents and in neuroscience research. Appl Microbiol Biotechnol 99(23):9847-9863. https://doi.org/10.1007/s00253-015-6941-2

\section{CAS}

Article

PubMed

Google Scholar 
Alves de Vasconcelos M, Sena da Penha S, Castro E Silva VR, Leite TA, Bezerra de Souza E, Silva Souza BW, Teixeira EH, Coelho da Silva AL (2018) Fruticulosin: A novel type 2 ribosome-inactivating protein from Abrus fruticulosus seeds that exhibits toxic and antileishmanial activity. Arch Biochem Biophys 658:46-53. https://doi.org/10.1016/j.abb.018.09.001

CAS

Article

PubMed

Google Scholar

Ballinger MJ, Gawryluk RMR, Perlman SJ (2019) Toxin and genome evolution in a Drosophila defensive symbiosis. Genome Biol Evol 11(1):253-262. https://doi.org/10.1093/gbe/evy272

CAS

Article

PubMed

Google Scholar

Barbieri L, Polito L, Bolognesi A, Ciani M, Pelosi E, Farini V, Jha AK, Sharma N, Vivanco JM, Chambery A, Parente A, Stirpe F (2006) Ribosome-inactivating proteins in edible plants and purification and characterization of a new ribosome -inactivating protein from Cucurbita moschata.

Biochim Biophys

Acta 1760(5):783-792.

https://doi.org/10.1016/j.bbagen.2006.01.002

CAS

Article 
PubMed

Google Scholar

Bass HW, Krawetz JE, OBrian GR, Zinselmeier C, Habben JE, Boston RS (2004) Maize ribosome inactivating proteins (RIPs) with distinct expression patterns have similar requirements for proenzyme activation. J Exp Bot 55(406):2219-2233

CAS

Article

Google Scholar

Basu D, Tumer NE (2015) Do the A subunits contribute to the differences in the toxicity of Shiga toxin 1 and Shiga toxin 2? Toxins (Basel) 7(5):1467-1485. https://doi.org/10.3390/toxins7051467

CAS

Article

Google Scholar

Bolognesi A, Bortolotti M, Maiello S, Battelli MG, Polito L (2016) Ribosome-inactivating proteins from plants: historic molecules. 21(12):E1627.al Overview. https://doi.org/10.3390/molecules21121627

Bolognesi A, Bortolotti M, Battelli MG, Polito L (2017) Hyperuricaemia, xanthine oxidoreductase and ribosome-inactivating proteins from plants: the contributions of Fiorenzo Stirpe to frontline research. Molecules 22(2):E206. https://doi.org/10.3390/molecules22020206 
CAS

Article

PubMed

Google Scholar

Chan WY, Ng TB, Lam JS, Wong JH, Chu KT, Ngai PH, Lam SK, Wang HX (2010) The mushroom ribosome-inactivating protein lyophyllin exerts deleterious effects on mouse embryonic development in vitro. Appl Microbiol Biotechnol 85(4):985-993. https://doi.org/10.1007/s00253-009-2048-y

CAS

Article

PubMed

Google Scholar

Chan YS, Ng TB (2016) Shiga toxins: from structure and mechanism to applications. Appl Microbiol Biotechnol 100(4):1597-1610. https://doi.org/10.1007/s00253-015-7236-3

Chauhan V, Chauhan R, Sonkar P, Dhaked RK (2019) Biochemical characterization of in vitro reconstituted biologically active recombinant Shiga toxin. Protein Pept Lett 26(3):227-234. https://doi.org/10.2174/0929866526666181228161834

CAS

Article 
PubMed

Google Scholar

Cheung RC, Wong JH, Pan WL, Chan YS, Yin CM, Dan XL, Wang HX, Fang EF, Lam SK, Ngai PH, Xia LX, Liu F, Ye XY, Zhang GQ, Liu QH, Sha O, Lin P, Ki C, Bekhit AA (2014) Bekhit Ael-D, Wan DC, Ye XJ, Xia J, Ng TB. Antifungal and antiviral products of marine organisms. Appl Microbiol Biotechnol 98(8):3475-3494. https://doi.org/10.1007/s00253-014-5575-0

\section{CAS}

Article

PubMed

PubMed Central

Google Scholar

Chuang WP, Herde M, Ray S, Castano-Duque L, Howe GA, Luthe DS (2014) Caterpillar attack triggers accumulation of the toxic maize protein RIP2. New Phytol 201(3):928-939. https://doi.org/10.1111/nph.12581

Citores L, Ferreras JM, Muñoz R, Benítez J, Jiménez P, Girbés T (2002) Targeting cancer cells with transferrin conjugates containing the non-toxic type 2 ribosome-inactivating proteins nigrin b or ebulin I. Cancer Lett 184(1):29-35. https://doi.org/10.1016/s0304-3835(02)001696/

CAS

Article 
PubMed

Google Scholar

Collins RA, Ng TB (1997) Polysaccharopeptide from Coriolus versicolor has potential for use against human immunodeficiency virus type 1 infection. Life Sci 60(25):PL383-PL387

CAS

Article

Google Scholar

Collins RA, Ng TB, Fong WP, Wan CC, Yeung HW (1997) Inhibition of glycohydrolase enzymes by aqueous extracts of Chinese medicinal herbs in a microplate format. Biochem Mol Biol Int 42(6):1163-1169

CAS

PubMed

Google Scholar

De Benito FM, Citores L, Iglesias R, Ferreras JM, Soriano F, Arias J, Méndez E, Girbés T (1995) Ebulitins: a new family of type 1 ribosome-inactivating proteins (rRNA N-glycosidases) from leaves of Sambucus ebulus $\mathrm{L}$. that coexist with the type 2 ribosome-inactivating protein ebulin 1. FEBS Lett 360(3):299-302. https://doi.org/10.1016/0014-5793(95)00130-2

Article

PubMed 
Google Scholar

De Virgilio M, Lombardi A, Caliandro R, Fabbrini MS (2010) Ribosome-inactivating proteins: from plant defense to tumor attack. Toxins (Basel) 2(11):2699-2737. https://doi.org/10.3390/toxins2112699

De Zaeytijd J, Van Damme EJ (2017) Extensive evolution of cereal ribosome-inactivating proteins translates into unique structural features, activation mechanisms, and physiological roles. Toxins (Basel) 9(4):E123. https://doi.org/10.3390/toxins9040123

Dong TX, Ng TB, Yeung HW, Wong RN (1994) Isolation and characterization of a novel ribosome-inactivating protein, beta-kirilowin, from the seeds of Trichosanthes kirilowii. Biochem Biophys Res Commun 199(1):387-393

CAS

Article

Google Scholar

Dowd PF, Holmes RA, Pinkerton TS, Johnson ET, Lagrimini LM, Boston RS (2006) Relative activity of a tobacco hybrid expressing high levels of a tobacco anionic peroxidase and maize ribosome inactivating protein against Helicoverpa zea and Lasioderma serricorne. J Agric Food Chem 54(7):2629-2634. https://doi.org/10.1021/jf058180p

CAS

Article

PubMed

Google Scholar 
Dowd PF, Johnson ET, Price NP (2012) Enhanced pest resistance of maize leaves expressing monocot crop plant-derived ribosome-inactivating protein and agglutinin. J Agric Food Chem 60(43):10768-75. https://doi.org/10.1021/jf3041337

Endo Y, Tsurugi K, Lambert JM (1988) The site of action of six different ribosome-inactivating proteins from plants on eukaryotic ribosomes: the RNA N-glycosidase activity of the proteins. Biochem Biophys Res Commun 150(3):1032-1036. https://doi.org/10.1016/0006$291 \times(88) 90733-4$

Fabbrini MS, Katayama M, Nakase I, Vago R (2017) Plant ribosome-inactivating proteins: rogesses, challenges and biotechnological applications (and a few digressions). Toxins (Basel) 9(10):E314. https://doi.org/10.3390/toxins9100314

\section{CAS}

Article

Google Scholar

Fang EF, Zhang CZ, Ng TB, Wong JH, Pan WL, Ye XJ, Chan YS, Fong WP (2012) Momordica charantia lectin, a type II ribosome inactivating protein, exhibits antitumor activity toward human nasopharyngeal carcinoma cells in vitro and in vivo. Cancer Prev Res (Phila) 5(1):109121. https://doi.org/10.1158/1940-6207.CAPR-11-0203

CAS

Article

Google Scholar

Ferreras JM, Citores L, Iglesias R, Jiménez P, Girbés T (2011) Use of ribosome-inactivating proteins from Sambucus for the construction of immunotoxins and conjugates for cancer therapy. Toxins (Basel). 3(5):420-441. https://doi.org/10.3390/toxins3050420 
Fong WP, Poon YT, Wong TM, Mock JW, Ng TB, Wong RN, Yao QZ, Yeung HW (1996) A highly efficient procedure for purifying the ribosome-inactivating proteins alpha- and betamomorcharins from Momordica charantia seeds, $\mathrm{N}$-terminal sequence comparison and establishment of their N-glycosidase activity. Life Sci 59(11):901-909. https://doi.org/10.1016/0024-3205(96)00388-8

CAS

Article

PubMed

Google Scholar

Gao W, Ling J, Zhong X, Liu W, Zhang R, Yang H, Cao H, Zhang Z (1994) Luffin-S--a small novel ribosome-inactivating protein from Luffa cylindrica. Characterization and mechanism studies. FEBS Lett 347(2-3):257-260. https://doi.org/10.1016/0014-5793(94)00554-0

CAS

Article

PubMed

Google Scholar

Garcia-Arraez MG, Masson F, Escobar JCP, Lemaitre B (2019) Functional analysis of RIP toxins from the Drosophila endosymbiont Spiroplasma poulsonii. BMC Microbiol 19(1):46. https://doi.org/10.1186/s12866-019-1410-1

Article

PubMed 
PubMed Central

Google Scholar

Giansanti F, Flavell DJ, Angelucci F, Fabbrini MS, Ippoliti R (2018) Strategies to improve the clinical utility of saporin-based targeted toxins. Toxins (Basel) 10(2):E82. https://doi.org/10.3390/toxins10020082

Girbés T, Citores L, Iglesias R, Ferreras JM, Muñoz R, Rojo MA, Arias FJ, García JR, Méndez E, Calonge M (1993) Ebulin 1, a nontoxic novel type 2 ribosome-inactivating protein from Sambucus ebulus L. leaves. J Biol Chem 268(24):18195-18199

PubMed

Google Scholar

Girbes T, Ferreras JM, Arias FJ, Muñoz R, Iglesias R, Jimenez P, Rojo MA, Arias $\mathrm{Y}$, Perez $\mathrm{Y}$, Benitez J, Sanchez D, Gayoso MJ (2003) Non-toxic type 2 ribosome-inactivating proteins (RIPs) from Sambucus: occurrence, cellular and molecular activities and potential uses. Cell Mol Biol (Noisy-le-grand) 49(4):537-545

CAS

Google Scholar

Hamilton PT, Peng F, Boulanger MJ, Perlman SJ (2016) A ribosome-inactivating protein in a Drosophila defensive symbiont. Proc Natl Acad Sci U S A 113(2):350-355. https://doi.org/10.1073/pnas.1518648113

Hey TD, Hartley M, Walsh TA (1995) Maize ribosome-inactivating protein (b-32). Homologs in related species, effects on maize ribosomes, and modulation of activity by pro-peptide deletions. Plant Physiol 107(4):1323-1332. https://doi.org/10.1104/pp.107.4.1323 
Hou FJ, Liu RS, Liu WY (2002) Cinphorin: a novel type II ribosome-inactivating protein with miniature active A-chain. Prog Biochem Biophys 29(4):531-532

\section{CAS}

Google Scholar

Islam MR, Hirayama H, Funatsu G (1991) Complete amino acid sequence of luffin-b, a ribosome-inactivating protein from sponge gourd (Luffa cylindrica) seeds. Agric Biol Chem 55(1):229-238

\section{CAS}

PubMed

Google Scholar

Kaur I, Gupta RC, Puri M (2011) Ribosome inactivating proteins from plants inhibiting viruses. Virol Sin 26(6):357-365. https://doi.org/10.1007/s12250-011-3223-8

\section{CAS}

Article

PubMed

Google Scholar 
Kim JK, Jang IC, Wu R, Zuo WN, Boston RS, Lee YH, Ahn IP, Nahm BH (2003) Co-expression of a modified maize ribosome-inactivating protein and a rice basic chitinase gene in transgenic rice plants confers enhanced resistance to sheath blight. Transgenic Res 12(4):475-84

Krawetz JE, Boston RS (2000) Substrate specificity of a maize ribosome-inactivating protein differs across diverse taxa. Eur J Biochem 267(7):1966-1974. https://doi.org/10.1046/j.14321327.2000.01200.x

CAS

Article

PubMed

Google Scholar

Lam SK, Ng TB (2001a) First simultaneous isolation of a ribosome inactivating protein and an antifungal protein from a mushroom (Lyophyllum shimeji) together with evidence for synergism of their antifungal effects. Arch Biochem Biophys 393(2):271-280. https://doi.org/10.1006/abbi.2001.2506

CAS

Article

PubMed

Google Scholar

Lam SK, Ng TB (2001b) Hypsin, a novel thermostable ribosome-inactivating protein with antifungal and antiproliferative activities from fruiting bodies of the edible mushroom Hypsizigus marmoreus. Biochem Biophys Res Commun 285(4):1071-1075. https://doi.org/10.1006/bbrc.2001.5279 


\section{CAS}

Article

PubMed

Google Scholar

Lam SK, Ng TB (2011) Lectins: production and practical applications. Appl Microbiol Biotechnol 89(1):45-55. https://doi.org/10.1007/s00253-010-289-9

CAS

Article

PubMed

Google Scholar

Lam SS, Wang H, Ng TB (1998) Purification and characterization of novel ribosome inactivating proteins, alpha- and beta-pisavins, from seeds of the garden pea Pisum sativum. Biochem Biophys Res Commun 253(1):135-142. https://doi.org/10.1006/bbrc./1998.9764

Lapadula WJ, Marcet PL, Mascotti ML, Sanchez-Puerta MV, Juri AM (2017) Metazoan ribosome inactivating protein encoding genes acquired by horizontal gene transfer. Sci Rep 7(1):1863. https://doi.org/10.1038/s41598-017-01859-1

CAS

Article

PubMed 
PubMed Central

Google Scholar

Lapadula WJ, Sánchez Puerta MV, Juri Ayub M (2013) Revising the taxonomic distribution, origin and evolution of ribosome inactivating protein genes. PLoS One 8(9):e72825. https://doi.org/10.1371/journal.pone.0072825

Law SK, Wang RR, Mak AN, Wong KB, Zheng YT, Shaw PC (2010) A switch-on mechanism to activate maize ribosome-inactivating protein for targeting HIV-infected cells. Nucleic Acids Res 38(19):6803-6812. https://doi.org/10.1093/nar/gkq551

Li F, Xia HC, Yang XX, Hu WG, Li Z, Zhang ZC (2003a) Purification and partial characterization of luffin $\mathrm{P} 1$, a peptide with translational inhibitory activity and trypsin inhibitory activity, from seeds of Luffa cylindrica. Sheng Wu Hua Xue Yu Sheng Wu Wu Li Xue Bao (Shanghai). 35(9):847-852

CAS

PubMed

Google Scholar

Li F, Yang XX, Hu WG, Xia HC, Li Z, Zhang ZC (2003b) Purification and characterization of trichokirin-S1, a novel ribosome-inactivating peptide from seeds of Trichosanthes kirilowii. Sheng Wu Hua Xue Yu Sheng Wu Wu Li Xue Bao (Shanghai). 35(9):841-846

CAS

PubMed

Google Scholar 
Li F, Yang XX, Xia HC, Zeng R, Hu WG, Li Z, Zhang ZC (2003c) Purification and characterization of Luffin $\mathrm{P} 1$, a ribosome-inactivating peptide from the seeds of Luffa cylindrica. Peptides. 24(6):799-805. https://doi.org/10.1016/s0196-9781(03)00173-6

\section{CAS}

Article

PubMed

Google Scholar

Ling J, Liu WY (1996) Cytotoxicity of two new ribosome-inactivating proteins, cinnamomin and camphorin, to carcinoma cells. Cell Biochem Funct 14(3):157-161. https://doi.org/10.1002/cbf.667

CAS

Article

PubMed

Google Scholar

Liu MM, Xing YM, Guo SX (2017) Molecular cloning and prokaryotic expression of a type II ribosome inactivating protein from Polyporus umbellatus. Yao Xue Xue Bao 52(2):327-332

PubMed

Google Scholar 
Liu RS, Yang JH, Liu WY (2002 Oct) Isolation and enzymatic characterization of lamjapin, the first ribosome- inactivating protein from cryptogamic algal plant (Laminaria japonica a). Eur J Biochem 269(19):4746-4752. https://doi.org/10.1046/j.1432-1033.2002.03165.x

Liu WY (2017) Research on ribosome-inactivating proteins from angiospermae to gymnospermae and cryptogamia. Am J Transl Res 9(12):5719-5742

\section{CAS}

PubMed

PubMed Central

Google Scholar

Lönnerdal B, Erdmann P, Thakkar SK, Sauser J, Destaillats F (2017) Longitudinal evolution of true protein, amino acids and bioactive proteins in breast milk: a developmental perspective. $J$ Nutr Biochem 41:1-11. https://doi.org/10.1016/j.jnutbio.2016.06.001

Ma C, Li Y, Li Z, Huang H, Xu K, Xu H, Bai J, Li X, Zhao G (2012) Synthesis and purification of a toxin-linked conjugate targeting epidermal growth factor receptor in Escherichia coli. Protein Expr Purif 83(1):1-7. https://doi.org/10.1016/j.pep.2012.02.011

Ma Q, Yao G, Wu S, Li H, Li J, Dong Y (2000) Crystallization and preliminary X-ray analysis of luffaculin, a ribosome-inactivating protein from sponge-gourd seeds. Acta Crystallogr D Biol Crystallogr 56(Pt 2):185-186. https://doi.org/10.1107/s0907444999014110

Mak AN, Wong YT, An YJ, Cha SS, Sze KH, Au SW, Wong KB, Shaw PC (2007) Structurefunction study of maize ribosome-inactivating protein: implications for the internal inactivation region and the sole glutamate in the active site. Nucleic Acids Res 35(18):6259-6257. https://doi.org/10.1093/nar/gkm687

Mateos M, Silva NO, Ramirez P, Higareda-Alvear VM, Aramayo R, Erickson JW (2019) Effect of heritable symbionts on maternally derived embryo transcripts. Sci Rep 9(1):8847. https://doi.org/10.1038/s41598-019-45371-0 
Muñoz R, Arias Y, Ferreras JM, Jiménez P, Rojo MA, Girbés T (2001) Sensitivity of cancer cell lines to the novel non-toxic type 2 ribosome-inactivating protein nigrin b. Cancer Lett 167(2):163-169. https://doi.org/10.1016/s0304-3835(01)00477-3

Article

PubMed

Google Scholar

Neshani A, Zare H, Akbari Eidgahi MR, Hooshyar Chichaklu A, Movaqar A, Ghazvini K (2019) Review of antimicrobial peptides with anti-Helicobacter pylori activity. Helicobacter. 24(1):e12555. https://doi.org/10.1111/hel.12555

CAS

Article

PubMed

Google Scholar

Ng TB, Chan WY, Yeung HW (1992) Proteins with abortifacient, ribosome inactivating immunomodulatory, antitumor and anti-AIDS activities from Cucurbitaceae plants. Gen Pharmacol 23(4):579-590. https://doi.org/10.1016/0306-3623(92)90131-3

CAS

Article

PubMed 
Google Scholar

Ng TB, Cheung RC, Wong JH, Chan WY (2015) Proteins, peptides, polysaccharides, and nucleotides with inhibitory activity on human immunodeficiency virus and its enzymes. Appl Microbiol Biotechnol 99(24):10399-10414. https://doi.org/10.1007/s00253-015-6997-z

\section{CAS}

Article

PubMed

Google Scholar

Ng TB, Cheung RCF, Wong JH, Chan YS, Dan X, Pan W, Wang H, Guan S, Chan K, Ye X, Liu F, Xia L, Chan WY (2016) Fungal proteinaceous compounds with multiple biological activities. Appl Microbiol Biotechnol 100(15):6601-6617. https://doi.org/10.1007/s00253-0167671-9

Ng TB, Lam JS, Wong JH, Lam SK, Ngai PH, Wang HX, Chu KT, Chan WY (2010) Differential abilities of the mushroom ribosome- inactivating proteins hypsin and velutin to perturb normal development of cultured mouse embryos. Toxicol in Vitro 24(4):1250-1257. https://doi.org/10.1016/j.tiv.2010.02.003

$\mathrm{Ng}$ TB, Lam YW, Wang H (2003a) Calcaelin, a new protein with translation-inhibiting, antiproliferative and antimitogenic activities from the mosaic puffball mushroom Calvatia caelata. Planta Med 69(3):212-217. https://doi.org/10.1055/s-2003-38492

$\mathrm{Ng}$ TB, Parkash A (2002) Hispin, a novel ribosome inactivating protein with antifungal activity from hairy melon seeds. Protein Expr Purif 26(2):211-217. https://doi.org/10.1016/s10465928(02)00511-9 
Article

PubMed

Google Scholar

Ng TB, Parkash A, Tso WW (2002) Purification and characterization of moschins, arginineglutamate-rich proteins with translation-inhibiting activity from brown pumpkin (Cucurbita moschata) seeds. Protein Expr Purif 26(1):9-13. https://doi.org/10.1016/s10465928(02)00500-4

CAS

Article

PubMed

Google Scholar

$\mathrm{Ng}$ TB, Parkash A, Tso WW (2003b) Purification and characterization of alpha- and betabenincasins, arginine/glutamate-rich peptides with translation-inhibiting activity from wax gourd seeds. Peptides 24(1):11-16. https://doi.org/10.1016/s0196-9781(02)00271-1

$\mathrm{Ng}$ TB, Wang HX (2004) Flammin and velin: new ribosome inactivating polypeptides from the mushroom Flammulina velutipes. https://doi.org/10.1016/j.peptides.2004.03.007

Ng YM, Yang Y, Sze KH, Zhang X, Zheng YT, Shaw PC (2011) Structural characterization and anti-HIV-1 activities of arginine/glutamate-rich polypeptide Luffin P1 from the seeds of sponge gourd (Luffa cylindrica). J Struct Biol 174(1):164-172. https://doi.org/10.1016/j.jsb.2010.12.007 
Article

PubMed

Google Scholar

Nielsen K, Payne GA, Boston RS (2001) Maize ribosome-inactivating protein inhibits normal development of Aspergillus nidulans and Aspergillus flavus. Mol Plant-Microbe Interact 14(2):164-172. https://doi.org/10.1094/MPMI.2001.14.2.164

CAS

Article

PubMed

Google Scholar

Pan WL, Wong JH, Fang EF, Chan YS, Ye XJ, Ng TB (2013) Differential inhibitory potencies and mechanisms of the type I ribosome inactivating protein marmorin on estrogen receptor (ER)- positive and ER-negative breast cancer cells. Biochim Biophys Acta 1833(5):987-996. https://doi.org/10.1016/j.bbamcr.2012.12.013

CAS

Article

PubMed

Google Scholar 
Parkash A, Ng TB, Tso WW (2002a) Purification and characterization of charantin, a napinlike ribosome-inactivating peptide from bitter gourd (Momordica charantia) seeds. J Pept Res 59(5):197-202. https://doi.org/10.1034/j.1399-3011.2002.00978.x

\section{CAS}

Article

PubMed

Google Scholar

Parkash A, Ng TB, Tso WW (2002b) Isolation and characterization of luffacylin, a ribosome inactivating peptide with anti-fungal activity from sponge gourd (Luffa cylindrica) seeds. Peptides. 23(6):1019-1024. https://doi.org/10.1016/s0196-9781(02)00045-1

Pasetto M, Barison E, Castagna M, Della Cristina P, Anselmi C, Colombatti M (2012) Reductive activation of type 2 ribosome-inactivating proteins is promoted by transmembrane thioredoxin-related protein. $J$ Biol Chem 287(10):7367-7373. https://doi.org/10.1074/jbc.M111.316828

Pizzo E, Pane K, Bosso A, Landi N, Ragucci S, Russo R, Gaglione R, Torres MDT, de la Fuente-Nunez C, Arciello A, Di Donato A, Notomista E, Di Maro A (2018) Novel bioactive peptides from PD-L1/2, a type 1 ribosome inactivating protein from Phytolacca dioica $\mathrm{L}$. evaluation of their antimicrobial properties and anti-biofilm activities. Biochim Biophys Acta Biomembr 1860(7):1425-1435. https://doi.org/10.1016/j.bbamem.2018.04.010

\section{CAS}

Article

PubMed

Google Scholar 
Pizzo E, Zanfardino A, Di Giuseppe AM, Bosso A, Landi N, Ragucci S, Varcamonti M, Notomista E, Di Maro A (2015) A new active antimicrobial peptide from PD-L4, a type 1 ribosome inactivating protein of Phytolacca dioica L.: A new function of RIPs for plant defence? FEBS Lett 589(19 Pt B):2812-2818. https://doi.org/10.1016/j.febslet.2015.08.018

Polito L, Bortolotti M, Pedrazzi M, Bolognesi A (2011) Immunotoxins and other conjugates containing saporin-s6 for cancer therapy. Toxins (Basel) 3(6):697-720. https://doi.org/10.3390/toxins3060697

Pu Z, Lu BY, Liu WY, Jin SW (1996) Characterization of the enzymatic mechanism of gammamomorcharin, a novel ribosome-inactivating protein with lower molecular weight of 11,500 purified from the seeds of bitter gourd (Momordica charantia). Biochem Biophys Res Commun 229(1):287-294. https://doi.org/10.1006/bbrc.1996.1794

\section{CAS}

Article

PubMed

Google Scholar

Reyes AG, Geukens N, Gutschoven P, De Graeve S, De Mot R, Mejía A, Anné J (2010) The Streptomyces coelicolor genome encodes a type I ribosome-inactivating protein. Microbiology. 156(Pt 10):3021-3030. https://doi.org/10.1099/mic.0.039073-0

Shafee TM, Lay FT, Phan TK, Anderson MA, Hulett MD (2017) Convergent evolution of defensin sequence, structure and function. Cell Mol Life Sci. 74(4):663-682. https://doi.org/10.1007/s00018-016-2344-5

\section{CAS}

Article 
Google Scholar

Shu SH, Xie GZ, Guo XL, Wang M (2009) Purification and characterization of a novel from seeds of Trichosanthes kirilowii Maxim. Protein Expr Purif 67(2):120-125. https://doi.org/10.1016/j.pep.2009.03.004

\section{CAS}

Article

PubMed

Google Scholar

Sierra JM, Fusté E, Rabanal F, Vinuesa T, Viñas M (2017) An overview of antimicrobial peptides and the latest advances in their development. Expert Opin Biol Ther 17(6):663-676. https://doi.org/10.1080/14712598.2017.1315402

Stirpe F, Lappi DA (2014) Ribosome-inactivating proteins. Ricins and related Proteins. John Wiley \& Sons Ltd

Tai NW, Li F, Li Z, Zhuang DH, Zhang ZC (2000) Purification and partial characterization of Strichokirin, a new small ribosome-inactivating protein, from seeds of Trichosanthes kirilowii. Sheng Wu Hua Xue Yu Sheng Wu Wu Li Xue Bao (Shanghai) 32(5):495-498

\section{CAS}

Google Scholar

Tesh V (2012a) Activation of cell stress response pathways by Shiga toxins. Cell Microbiol 14(1):1-9. https://doi.org/10.1111/j.1462-5822.2011.01684.x 
Tesh VL (2012b) The induction of apoptosis by Shiga toxins and ricin. Curr Top Microbiol Immunol 357:137-178. https://doi.org/10.1007/82_2011_155

\section{CAS}

Article

PubMed

Google Scholar

Tsang KY, Ng TB (2001) Isolation and characterization of a new ribosome inactivating protein, momorgrosvin, from seeds of the monk's fruit Momordica grosvenorii. Life Sci 68(7):773-784. https://doi.org/10.1016/s0024-3205(00)00980-2

\section{CAS}

Article

PubMed

Google Scholar

Walsh TA, Morgan AE, Hey TD (1991) Characterization. And molecular cloning of a proenzyme form of a ribosome-inactivating protein from maize. Novel mechanism of proenzyme activation by proteolytic removal of a 2.8-kilodalton internal peptide segment. J Biol Chem 266(34):23422-23427

CAS

PubMed 
Google Scholar

Wang $\mathrm{H}, \mathrm{Ng}$ TB (2001a) Isolation and characterization of velutin, a novel low-molecular-weight ribosome-inactivating protein from winter mushroom (Flammulina velutipes) fruiting bodies. Life Sci 68(18):2151-2158. https://doi.org/10.1016/s0024-3205(01)01023-2

\section{CAS}

Article

PubMed

Google Scholar

Wang $\mathrm{H}, \mathrm{Ng}$ TB (2002) Luffangulin, a novel ribosome inactivating peptide from ridge gourd (Luffa acutangula) seeds. Life Sci 70(8):899-906. https://doi.org/10.1016/s00243205(01)01466-7

\section{CAS}

Article

PubMed

Google Scholar

Wang HX, Ng TB (2000a) Lagenin, a novel ribosome-inactivating protein with ribonucleolytic activity from bottle gourd (Lagenaria siceraria) seeds. Life Sci 67(21):2631-2638. https://doi.org/10.1016/s0024-3205(00)00846-8 


\section{CAS}

Article

PubMed

Google Scholar

Wang HX, Ng TB (2000b) Flammulin: a novel ribosome-inactivating protein from fruiting bodies of the winter mushroom Flammulina velutipes. Biochem Cell Biol 78(6):699-702. https://doi.org/10.1139/000-087

CAS

Article

PubMed

Google Scholar

Wang HX, Ng TB (2001b) Isolation of pleuturegin, a novel ribosome-inactivating protein from fresh sclerotia of the edible mushroom Pleurotus tuber-regium. Biochem Biophys Res Commun 288(3):718-721. https://doi.org/10.1006/bbrc.2001.5816

\section{CAS}

Article

PubMed

Google Scholar 
Wang HX, Ng TB (2003) Isolation of cucurmoschin, a novel antifungal peptide abundant in arginine, glutamate and glycine residues from black pumpkin seeds. Peptides. 24(7):969-972. https://doi.org/10.1016/s0196-9781(03)00191-8

Wang R, Gan C, Gao W, He W, Wang X, Peng Y, Zhuo J, Tan J, Peng X, Wu J, Luo G (2010) A novel recombinant immunotoxin with the smallest ribosome-inactivating protein Luffin P1: Tcell cytotoxicity and prolongation of allograft survival. J Cell Mol Med 14(3):578-586. https://doi.org/10.1111/j.1582-4934.2009.00840.x

CAS

Article

PubMed

Google Scholar

Wang RR, Au KY, Zheng HY, Gao LM, Zhang X, Luo RH, Law SK, Mak AN, Wong KB, Zhang MX, Pang W, Zhang GH, Shaw PC, Zheng YT (2015) The recombinant maize ribosomeinactivating protein transiently reduces viral load in SHIV89.6 infected Chinese Rhesus Macaques. Toxins (Basel) 7(1):156-169. https://doi.org/10.3390/toxins7010156

CAS

Article

Google Scholar

Wang S, Zhang Y, Liu H, He Y, Yan J, Wu Z, Ding Y (2012) Molecular cloning and functional analysis of a recombinant ribosome-inactivating protein (alpha-momorcharin) from Momordica charantia. Appl Microbiol Biotechnol 96(4):939-950. https://doi.org/10.1007/s00253-0123886-6 
Article

PubMed

Google Scholar

Wong JH, Ng TB, Cheung RC, Ye XJ, Wang HX, Lam SK, Lin P, Chan YS, Fang EF, Ngai PH, Xia LX, Ye XY, Jiang Y, Liu F (2010) Proteins with antifungal properties and other medicinal applications from plants and mushrooms. Appl Microbiol Biotechnol 87(4):1221-1235. https://doi.org/10.1007/s00253-010-2690-2694

CAS

Article

PubMed

Google Scholar

Wong JH, Ng TB, Wang H, Cheung RCF, Ng CCW, Ye X, Yang J, Liu F, Ling C, Chan K, Ye X, Chan WY (2019) Antifungal proteins with antiproliferative activity on cancer cells and HIV-1 enzyme inhibitory activity from medicinal plants and medicinal fungi. Curr Protein Pept Sci 20(3):265-276. https://doi.org/10.2174/1389203719666180613085704

Wong JH, Wang HX, Ng TB (2008) Marmorin, a new ribosome inactivating protein with antiproliferative and HIV-1 reverse transcriptase inhibitory activities from the mushroom Hypsizigus marmoreus. Appl Microbiol Biotechnol 81(4):669-674. https://doi.org/10.1007/s00253-008-1639-3

CAS

Article 
PubMed

Google Scholar

Wong RN, Dong TX, Ng TB, Choi WT, Yeung HW (1996) Alpha-kirilowin, a novel ribosomeinactivating protein from seeds of Trichosanthes kirilowii (family Cucurbitaceae): a comparison with beta-kirilowin and other related proteins. Int J Pept Protein Res 47(1-2):103-109. https://doi.org/10.1111/j.1399-3011.1996.tb00816.x

Wong YT, Ng YM, Mak AN, Sze KH, Wong KB, Shaw PC (2012) Maize ribosome-inactivating protein uses Lys158-lys161 to interact with ribosomal protein P2 and the strength of interaction is correlated to the biological activities. PLoS One 7(12):e49608. https://doi.org/10.1371/journal.pone.0049608

CAS

Article

PubMed

PubMed Central

Google Scholar

Wu TH, Chow LP, Lin JY (1998) Sechiumin, a ribosome-inactivating protein from the edible gourd, Sechium edule Swartz--purification, characterization molecular cloning and expression. Eur J Biochem 255(2):400-408. https://doi.org/10.1046/j.1432-1327.1998.2550400.x

Xu H, He WJ, Liu WY (2004) A novel ribotoxin with ribonuclease activity that specifically cleaves a single phosphodiester bond in rat $28 \mathrm{~S}$ ribosomal RNA and inactivates ribosome. Arch Biochem Biophys 427(1):30-40. https://doi.org/10.1016/j.abb.2004.04.018 
Yan J, Yuan SS, Jiang LL, Ye XJ, Ng TB, Wu ZJ (2015) Plant antifungal proteins and their applications in agriculture. Appl Microbiol Biotechnol 99(12):4961-4981. https://doi.org/10.1007/s00253-015-6654-6656

CAS

Article

PubMed

Google Scholar

Yang Y, Mak AN, Shaw PC, Sze KH (2010) Solution structure of an active mutant of maize ribosome- inactivating protein (MOD) and its interaction with the ribosomal stalk protein $\mathrm{P} 2 . \mathrm{J}$ Mol Biol 395(5):897-907. https://doi.org/10.1016/j.jmb.2009.10.051

Yeung HW, Li WW (1987) Beta-trichosanthin: a new abortifacient protein from the Chinese drug, wangua, Trichosanthes cucumeroides. Int J Pept Protein Res 29(3):289-292. https://doi.org/10.1111/j.1399-3011.1987.tb02256.x

Zeng M, Zheng M, Lu D, Wang J, Jiang W, Sha O (2015) Anti-tumor activities and apoptotic mechanism of ribosome-inactivating proteins. Chin $J$ Cancer 34(8):325-334. https://doi.org/10.1186/s40880-015-0030-x

Zhou Y, Li XP, Kahn JN, Tumer NE (2018) Functional assays for measuring the catalytic activity of ribosome inactivating proteins. Toxins (Basel) 10(6):E240. https://doi.org/10.3390/toxins 10060240

Zhu F, Zhou YK, Ji ZL, Chen XR (2018) The plant ribosome-inactivating proteins play important roles in defense against pathogens and insect pest attacks. Front Plant Sci 9:146. https://doi.org/10.3389/fpls.2018.0014

Article

PubMed 
PubMed Central

Google Scholar

Download references

Funding

We gratefully acknowledge the award of HMRF research grant (no. 12131221) from Food and Health Bureau, the Government of Hong Kong Special Administrative Region, and a grant from National Natural Science Foundation of China (no. 81471927). We are thankful for support of the science and technology project of the Science and Technology Innovation Commission of Shenzhen (No. JCYJ20170818094217688) and the discipline construction project of biochemistry and molecular biology from National Development and Reform Commission (1452). 